\title{
Sistem Pemilihan Mesin Cuci Berdasarkan Kebutuhan Konsumen Menggunakan Fuzzy Tahani dan Promethee
}

\author{
Nur Huzumah ${ }^{1}$, Toni Arifn ${ }^{2}$ \\ ${ }^{1}$ Universitas BSI \\ e-mail: nhuzumah@gmail.com \\ ${ }^{2}$ Universitas BSI \\ e-mail: toni.tfn@bsi.ac.id
}

\begin{abstract}
Abstrak
Berdasarkan hasil survei terhadap kebutuhan mesin cuci pada tahun 2013 pertumbuhan mesin cuci nasional naik sebesar 28\%, Menurut data Euro Monitor tahun 2017, penetrasi mesin cuci di Indonesia selama lima tahun terakhir terus meningkat. Sekitar $74 \%$ masyarakat di Kota besar seperti Jakarta telah mengandalkan mesin cuci untuk membantu membersihkan pakaian. Namun pada pembelian mesin cuci, sebagian besar masyarakat masih tertarik dengan harga yang murah tanpa mengetahui spesifikasi detail mengenai mesin cuci yang akan dibeli apakah sesuai kebutuhan atau tidak. Karena kurangnya kesadaran masyarakat, maka dibuat sebuah sistem pendukung keputusan menggunakan metode fuzzy tahani dan promethee untuk meningkatkan kualitas rekomendasi mesin cuci sesuai kebutuhan konsumen. Metode fuzzy tahani digunakan untuk melakukan pengurutan data mesin cuci berdasarkan kriteria yang menghasilkan nilai 0 sampai dengan 1 . Setelah itu, metode promethee digunakan untuk mendapatkan bobot mesin cuci dan akan dilakukan pengurutan mesin cuci sesuai bobot yang didapat. Hasil penelitian ini menunjukkan bahwa adanya sistem pendukung keputusan yang dibangun, masyarakat yang ingin membeli mesin cuci dapat memilih dengan tepat, jelas dan objektif. Hasil akurasi yang dihasilkan adalah $90 \%$.
\end{abstract}

Kata Kunci: sistem pendukung keputusan, pemilihan mesin cuci, fuzzy tahani, promethee

\begin{abstract}
Based on results of survey about the needs of washing machines in 2013, the growth of national washing machines increased by 28\%. According to Euro Monitor Data of 2017, penetration of washing machines in Indonesia over the last five years continues to increase. About $74 \%$ of the people in big cities like Jakarta have relied on a washing machine to help clean clothes. However on the purchase of a washing machine, most of the people still interested in a cheap price without knowing detail specification of the washing machine which will be purchased whether as needed or not. Due the lack of public awareness, then made a decision support system using fuzzy tahani and promethee method to improve the quality of the washing machine recommendations according to needs of the consumers. Fuzzy tahani method is used to perform the washing machine data sorting based on the cirteria that yields a value of 0 to 1. After that, Promethee method is used to get weight of the washing machine and will do sorting machine according to the weight obtained. The results of this study indicate that a decision support system who has been built, people who want to buy a washing machine can choose the washing machine properly, cleary and objectively. The result of accuracy is $90 \%$.
\end{abstract}

Keywords: decision support system, washing machine selection, fuzzy tahani, promethee 


\section{Pendahuluan}

Menurut hasil survei pada tahun 2013 mengenai pertumbuhan penjualan mesin cuci nasional mencapai value sekitar Rp. 980 miliar atau naik 28\% (Astria, 2013). Semakin banyak penjualan mesin cuci dan tingkat pendapatan yang memadai akan mempengaruhi perilaku masyarakat yang cenderung menginginkan kebutuhan tertentu secara praktis, maka dengan itu mesin cuci sudah menjadi peran penting bagi masyarakat untuk keperluan pribadi ataupun masyarakat yang akan memanfaatkan mesin cuci sebagai sebuah usaha (laundry).

Salah satu masalah utama dalam pemilihan mesin cuci adalah kurangnya kesadaran mengenai informasi detail mengenai mesin cuci yang sesuai dengan kebutuhan, karena sebagian besar masyarakat masih tertarik membeli mesin cuci dengan harga murah, merk terkenal dan garansi yang panjang.

Dalam menentukan mesin cuci yang sesuai dengan kebutuhan masyarakat, perlu dibuat sebuah sistem pendukung keputusan agar masyarakat dapat menentukan sebuah mesin cuci yang sesuai dengan kriteria dan parameter kebutuhan mereka, apabila wanita karir dan ibu rumah tangga mereka harus memperhitungkan budget harga yang mereka inginkan, keadaan air dirumah mereka, pemakaian daya listrik rumah dan jumlah orang dalam keluarga. Apabila masyarakat yang akan memanfaatkannya sebagai usaha laundry mereka harus memperhitungkan tipe mesin cuci, jenis bukaan mesin cuci, kapasitas mesin cuci, dan kecepatan dari mesin cuci yang akan mereka gunakan.

Pada penelitian ini, metode yang digunakan dalam sebuah sistem pendukung keputusan yang akan dibangun untuk membantu para konsumen menentukan mesin cuci yang sesuai kebutuhan mereka dengan menggunakan kombinasi dari metode fuzzy tahani dan promethee. Dengan fuzzy tahani, proses evaluasi menjadi lebih akurat dengan memperhatikan nilai yang proporsional bagi setiap kriteria yang digunakan (Taufiq, 2016). Metode fuzzy tahani digunakan untuk melakukan urutan (ranking) data hasil penambangan dengan melakukan query fuzzy yang melibatkan variabel fuzzy (Yunus, Dahlan, \& Santoso, 2014). Sedangkan, metode promethee bertugas untuk menentukan peringkat akhir dari kualitas software, karena promethee memiliki kelebihan dalam proses pemeringkatan alternatif menggunakan fungsi preferensi dan bobot yang berbedabeda (Julianto, Setiawan, \& Aji, 2013).

Penelitian ini bertujuan untuk menghasilkan tipe mesin cuci berdasarkan pemilihan kriteria yang dilakukan oleh masyarakat dengan menggunakan metode fuzzy tahani dan promethee.

Beberapa penelitian yang menjadi acuan peneliti dalam melakukan penelitian menggunakan metode fuzzy tahani dan promethee diantaranya adalah yang dilakukan oleh Taufiq (2016) menentukan kinerja karyawan menggunakan metode fuzzy tahani berdasarkan kehadiran, kualitas kerja, kreatifitas, technical skills dan attitude.

Murat, Kazan \& Coskun (2015), melakukan penelitian terhadap kualitas kinerja dari sebuah sekolah terhadap kriteria prestasi, ketidakhadiran, aktifitas sosial dan kriteria proyek dengan menggunakan metode promethee.

Yunus, Dahlan \& Santoso (2014), dalam penelitiannya Algoritma C4.5 dan Fuzzy Tahani diterapkan untuk menangani pemilihan calon pendonor darah potensial sebagai bahan pertimbangan dalam meminta masyarakat sebagai pendonor darah sukarela dalam keadaan kritis. Metode algortima C4.5 sebagai eksplorasi data guna menemukan hubungan antara sejumlah variabel input dan fuzzy tahani digunakan untuk melakukan urutan data hasil penambangan.

Penelitian selanjutnya adalah penelitian yang dilakukan oleh Lemantara, Setiawan \& Aji (2013). Penelitian ini digunakan untuk merancang dan membangun sistem pendukung keputusan yang dapat memberikan saran untuk menentukan mahasiswa terbaik yang akan dikirim ke event. Metode kombinasi AHP dan promethee bertujuan untuk meningkatkan kualitas saran pemilihan mahasiswa dengan lebih cepat, tepat dan objektif.

Kemudian penelitian yang dilakukan oleh Arisandi, Sarita \& Sagala (2016), untuk membantu pengunjung dalam pemilihan hotel yang sesuai dengan kebutuhan. Kriteria yang digunakan sebagai indikator penelitian ialah harga, lokasi dan kelas. 
Selanjutnya, penelitian yang dilakukan oleh Rahmatullah, Prassetiyo \& Imran (2013) melakukan penelitian untuk evaluasi supplier bahan baku pembuatan kursi terbaik dengan variabel quality, harga, kapasitas supply, delivery dan garansi.

Penelitian yang dilakukan oleh Rusman (2016) menggunakan logika fuzzy tahani dalam penentuan lulusan terbaik yang dapat memudahkan pihak universitas dalam menentukan lulusan terbaik secara objektif berdasarkan kriteria seperti IPK, absensi, nilai TA, matkul unggulan 1 , matkul unggulan 2, matkul unggulan 3 dan matkul unggulan 4 .

Penelitian menggunakan logika fuzzy yang dilakukan oleh Trinorosimo \& Sumiati (2014) guna menghasilkan keputusan yang ontentik dan objektif pada pemilihan konsultan manajemen konstruksi, input yang digunakan sebagai kriteria terdiri dari bobot personil, bobot metodologi, dan bobot pengalaman.

Penelitian selanjutnya adalah penelitian yang dilakukan oleh Kazan, Ozcelik \& Hobikoglu (2015). Penelitian ini dilakukan untuk membantu partai politik dalam pemilihan kandidat deputi berdasarkan 15 kriteria. Adapun kriteria yang digunakan sebagai indikator penilaian, diantaranya penerapan prinsip-prinsip demokrasi, kepribadian dan karakter, struktur keluarga, tingkat pendidikan, pengalaman Negara, keahlian profesional, proyek, hubungan sosial, adposi Nasional budaya lain-lain, kedekatan budaya global, pengakuan dari daerah pemilihan, representasi kemapuan, evaluasi dan organiasai partai lokal, dan evaluasi puncak pihak manajemen.

Pada penelitian ini, kriteria yang akan digunakan dalam metode fuzzy tahani adalah harga, kapasitas, kecepatan, daya listrik, berat, panjang, lebar, tinggi, bukaan pintu, jenis tabung, garansi dan merk mesin cuci. Sedangkan kriteria yang digunakan dalam metode promethee adalah merk mesin cuci, sumber air, garansi, jumlah keluarga dan waktu kesibukan. Tujuan dari penelitian ini adalah menghasilkan mesin cuci yang sesuai dengan kebutuhan masyarakat dengan cara input parameter kriteria yang diinginkan.

\section{Metode Penelitian}

Pada penelitian ini menjelaskan tentang kriteria parameter yang akan diproses menggunakan dua metode yaitu metode fuzzy tahani dan promethee.

\section{Logika Fuzzy}

Logika fuzzy merupakan suatu nilai dapat bernilai true dan false secara bersamaan. Tingkat true atau false nilai dalam logika fuzzy tergantung pada bobot keanggotaan yang dimilikinya (Widodo \& Utomo, 2014). Logika fuzzy digunakan untuk menterjemahkan suatu nilai yang diekspresikan dalam bahasa (linguistic), misalkan untuk mengukur suhu dalam ruangan yang diekspresikan dengan dingin, hangat, atau panas.

Himpunan Fuzzy

Himpunan fuzzy pertama kali dikembangkan pada tahun 1965 oleh Lotfi A. Zadeh. Himpunan fuzzy adalah sekumpulan objek $(x)$ dimana masingmaisng objek memiliki nilai keanggotaan $(\mu)$ atau disebut juga dengan nilai kebenaran (Kuncahyo, B. Ginardi, R. \& Arieshanti, I., 2012). Himpunan fuzzy memiliki 2 (dua) atribut, yaitu:

a. Linguistic, yaitu penamaan suatu grup yang mewakili suatu keadaan atau kondisi tertentu dengan menggunakan bahasa alami, seperti muda, parobaya, dan tua.

b. Numeris, yaitu suatu nilai (angka) yang menunjukkan ukuran dari suatu variabel seperti $6,16,26$, dsb.

\section{Fungsi Keanggotaan}

Fungsi keanggotaan (membership function) adalah suatu kurva yang menunjukkan pemetaan titik-titik input data ke dalam nilai keanggotaannya (derajat keanggotaan) yang memiliki interval antara 0 sampai 1 (Kusumadewi, Sri., \& Hartati, 2006). Salah satu cara yang dapat digunakan untuk mendapatkan nilai keanggotaan adalah dengan melalui pendekatan fungsi. Berikut beberapa fungsi keanggotaan yang dapat digunakan:

a. Representasi Linier

Pemetaan input ke derajat keanggotaannya digambarkan sebagai suatu garis lurus. Terdapat dua keadaan himpunan fuzzy linier yaitu linier naik dan linier turun. Kenaikan himpunan dimulai pada nilai domain yang memiliki derajat keanggotaan nol [0] bergerak ke kanan menuju ke nilai domain yang memiliki derajat keanggotaan lebih tinggi $\mathrm{Hal}$ ini disajikan dalam gambar berikut: 


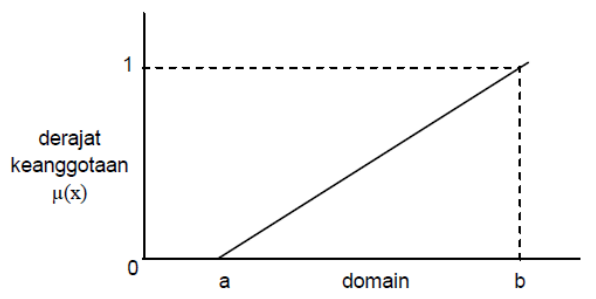

Gambar 1. Representasi Naik Sumber: (Tyas, 2013)

Fungsi keanggotaannya dapat ditulis sebagai:

$$
\mu[x]=\left\{\begin{array}{cc}
0 ; & x \leq a \\
\frac{x-a}{b-a} ; & a \leq x \leq b \\
1 ; & x \geq b
\end{array}\right.
$$

Selanjutnya, himpunan yang kedua adalah linier turun yang merupakan Garis lurus dimulai dari nilai domain dengan derajat keanggotaan tertinggi pada sisi kiri, kemudian bergerak menurun ke nilai domain yang memiliki derajat keanggotaan lebih rendah. Hal ini disajikan dalam gambar berikut:

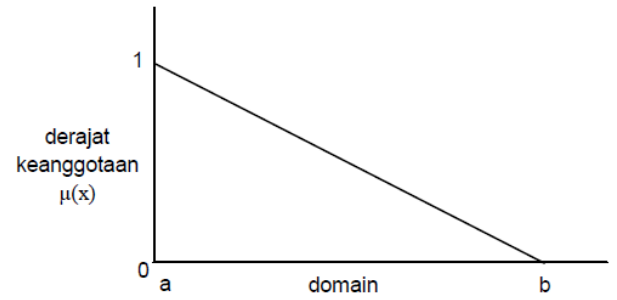

Sumber: (Tyas, 2013)

Gambar 2. Representasi Linier Turun

Fungsi keanggotaan representasi linier turun dapat ditulis sebagai:

$$
\mu[x]=\left\{\begin{array}{cc}
\frac{b-x}{b-a} ; & a \leq x \leq b \\
0 ; & x \geq b
\end{array}\right.
$$

b. Representasi Kurva Segitiga

Kurva segitiga pada dasarnya merupakan gabungan antara dua garis (linier) yang digambarkan seperti berikut:

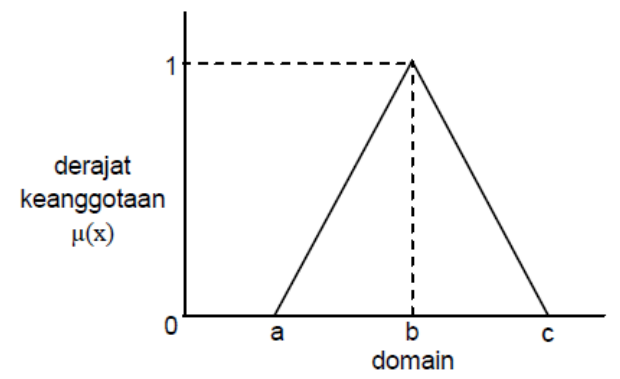

Sumber: (Tyas, 2013)

Gambar 3. Representasi Kurva Segitiga
Fungsi keanggotaannya dapat ditulis sebagai:

$$
\mu[x]=\left\{\begin{array}{lc}
0 ; & x \leq \text { a atau } x \geq c \\
\frac{x-a}{b-a} ; & a \leq x \leq b \\
\frac{c-x}{c-b} ; & b \leq x \leq c
\end{array}\right.
$$

c. Representasi Kurva Trapesium

Kurva trapesium pada dasarnya seperti bentuk segitiga, hanya saja ada beberapa titik yang memiliki nilai keanggotaan satu. Hal ini disajikan dalam gambar berikut:

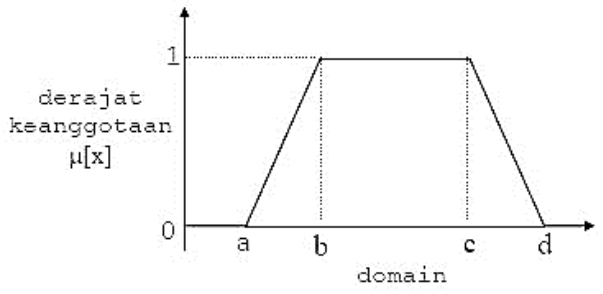

Sumber: (Tyas, 2013)

Gambar 4. Representasi Kurva Trapesium

Fungsi keanggotaannya dapat ditulis sebagai berikut:

$$
\mu[x]=\left\{\begin{array}{cc}
0 ; & x \leq a \text { atau } x \geq c \\
\frac{x-a}{b-a} ; & a \leq x \leq b \\
1 ; & b \leq x \leq c \\
\frac{a-x}{a-c} ; &
\end{array}\right.
$$

\section{Fuzzy Tahani}

Database fuzzy tahani merupakan salah satu metode fuzzy yang menggunakan sistem basis data sebagai pangkalan datanya. Jika suatu sistem diharapkan menghasilkan informasi yang bersifat linguistik atau ambigusous, maka kita dapat memanfaatkan model basis data (database) fuzzy. Model database fuzzy merupakan sistem database standar (klasik) yang dikembangkan dengan memasukkan data hasil fuzzyfikasi (fuzzyness) terhadap data tegas (crisp) yang ada dalam database (Yunus, Dahlan, \& Santoso, 2014).

Tahapan logika fuzzy model Tahani menurut (Kahar, 2013), yaitu:

a. Menggambarkan fungsi keanggotaan (membership function) untuk setiap kriteria atau variabel fuzzy, yaitu suatu kurva yang menunjukkan pemetaan titik-titik input data ke dalam nilai keanggotaannya (derajat keanggotaan) yang memiliki interval antara 0 sampa 
1. Salah satu cara yang dapat digunakan adalah dengan pendekatan fungsi keanggotaan berbentuk segitiga.

b. Fuzzyfikasi adalah fase pertama dari perhitungan fuzzy, yaitu pengubahan nilai tegas ke nilai fuzzy. Dimana setiap variabel fuzzy dihitung nilai derajat keanggotaannya terhadap setiap himpunan fuzzy.

c. Fuzzyfikasi query diasumsikan sebuah query konvensional (non-fuzzy) DBMS yang akan mencoba membuat dan menerapkan sebuah sistem dasar logika fuzzyquery atau disebut juga dengan pembentukan query dengan menggunakan relasi dasar.

d. Setelah diperoleh hasil operasi relasi dari pembentukan query, maka data hasil rekomendasi baik operator AND atau OR adalah nilai rekomendasi $>0$.

\section{Promethee}

Preference Ranking Organization Methode for Enrichment Evaluation (Promethee) merupakan salah satu metode penentuan ranking dalam Multi Criteria Decision Making (MCDM). Metode promethee mampu mengakomodir kriteria pemilihan yang bersifat kuantitatif dan kualitatif. Masalah utamanya adalah kesederhanaan, kejelasan dan kestabilan. Dugaan dari dominasi antar alternatif terhadap suatu kriteria yang digunakan dalam promethee adalah penggunaan nilai dalam hubungan antar nilai peringkatan antar alternatif (Suryadi \& Ramdhani, 2002).

Dalam fase pertama, nilai hubungan outranking berdasarkan pertimbangan dominasi masing-masing kriteria. Indeks preferensi ditentukan dan nilai outranking secara grafis disajikan berdasarkan preferensi dari pembuat keputusan.

Data dasar untuk analisis dalam metode promethee disajikan dalam tabel dibawah ini (Suryadi \& Ramdhani, 2002):

Tabel 1. Data Dasar Analisis Promethee

\begin{tabular}{|c|c|c|c|c|}
\hline & $\mathrm{f} 1$ & $\mathrm{f} 2$ & $\ldots$ & $\mathrm{fk}$ \\
\hline 1 & $\mathrm{fl}(\mathrm{a} 1)$ & f2(a1) & $\ldots$ & fk(a1) \\
\hline $\mathrm{a} 2$ & $\mathrm{f} 1(\mathrm{a} 2)$ & $\mathrm{f} 2(\mathrm{a} 2)$ & $\ldots$ & $\mathrm{fk}(\mathrm{a} 2)$ \\
\hline & $\cdots$ & $\ldots$ & $\ldots$ & $\ldots$ \\
\hline An & $\mathrm{f} 1$ (an) & $\mathrm{f} 2$ (an) & \begin{tabular}{|l|}
$\ldots$ \\
\end{tabular} & $\mathrm{fk}$ (an) \\
\hline
\end{tabular}

Sumber: (Suryadi \& Ramdhani, 2002)

Berikut adalah prosedur promethee: a. Menentukan beberapa alternatif yang ada dalam lingkup masalah dan akan dipilih sebagai solusi.

b. Menentukan beberapa kriteria yang akan digunakan selama proses pengambilan keputusan.

c. Menentukan dominasi kriteria. Hal ini didasarkan pada karakteristik tujuan dari setiap kriteria.

d. Menentukan tipe fungsi preferensi untuk setiap kriteria yang paling cocok didasarkan pada data dan pertimbangan di lapangan.

e. Memberikan nilai parameter untuk setiap kriteria berdasarkan preferensi yang telah dipilih.

f. Memberi nilai kriteria atau skor alternatif untuk masing-masing alternatif yang akan dilakukan proses pemilihan.

g. Membandingkan nilai kriteria untuk setiap alternatif dengan mempertimbangkan dominasi kriteria dan preferensi yang telah dipilih serta nilai parameter yang diberikan.

h. Promethee ranking. Dalam metode promethee ada 2 (2) macam perangkingan yang disandarkan pada hasil perhitungan, antara lain:

1) Perangkingan Parsial yang didasarkan pada nilai Leaving flow dan Enter Flow.

2) Perangkingan lengkap atau complete yang didasarkan pada nilai Net Flow.

Dugaan dari dominasi kriteria yang digunakan dalam Promethee adalah penggunaan nilai dalam hubungan outranking. Dalam fase pertama, nilai hubungan outranking berdasarkan pertimbangan dominasi masing-masing kriteria. Indeks preferensi ditentukan dan nilai outranking secara grafis disajikan berdasarkan preferensi dari pembuat keputusan. Untuk setiap node dalam grafik nilai outranking ditentukan berdasarkan leaving flow, dengan persamaan sebagai berikut:

$$
\varnothing+(a)=\left[\frac{1}{n-1}\right] \sum_{x \in A} \varphi(x, a)
$$
preferensi bahwa alternatif a lebih baik dari alternatif $\mathrm{x}$. leaving flow adalah jumlah dari nilai garis lengkung yang memiliki arah menjauh dari node a dan hal ini merupakan karakter pengukuran outranking. 


\section{Hasil dan Pembahasan}

Pada tahap ini akan dilakukan pembahasan perhitungan dari awal sampai dengan hasil akhir. Berikut langkah-langkah perhitungan pemilihan mesin cuci menggunakan metode fuzzy tahani dan promethee:

\subsection{Penentuan Variabel}

Pada tahap ini, peneliti menentukan 12 variabel yang menjadi dasar input parameter pada fuzzy tahani, sedangkan untuk promethee terdapat 10 variabel masing-masing untuk keperluan bisnis dan ibu rumah tangga. Data variabel untuk dijadikan input parameter fuzzy tahani terdapat pada tabel 2 .

Tabel 2. Data Variabel Fuzzy Tahani

\begin{tabular}{|c|l|}
\hline No & Kriteria \\
\hline 1. & Harga \\
\hline 2. & Kapasitas \\
\hline 3. & Kecepatan \\
\hline 4. & Konsumsi \\
\hline 5. & Berat \\
\hline 6. & Panjang \\
\hline 7. & Lebar \\
\hline 8. & Tinggi \\
\hline 9. & Bukaan Pintu \\
\hline 10. & Jenis Tabung \\
\hline 11. & Garansi \\
\hline 12. & Merk \\
\hline
\end{tabular}

Selanjutnya, 5 variabel yang digunakan promethee untuk keperluan rumah tangga terdapat pada tabel 3.

Tabel 3. Data Variabel Promethee Rumah Tangga

\begin{tabular}{|c|l|}
\hline No. & Kriteria \\
\hline 1. & Merk \\
\hline 2. & Sumber Air \\
\hline 3. & Garansi \\
\hline 4. & Jumlah Keluarga \\
\hline 5. & Kondisi Kesibukan \\
\hline
\end{tabular}

Untuk variabel yang digunakan promethee pada keperluan bisnis (laundry) terdapat pada tabel 4.

Tabel 4. Data Variabel Promethee Laundry

\begin{tabular}{|c|l|}
\hline No. & Kriteria \\
\hline 1. & Merk \\
\hline 2. & Garansi \\
\hline 3. & Tabung \\
\hline 4. & Kapasitas \\
\hline 5. & Bukaan Pintu \\
\hline
\end{tabular}

\subsection{Perhitungan Fuzzy Tahani}

Pada tahap ini menjelaskan tentang perhitungan manual dalam menentukan urutan data mesin cuci berdasarkan kriteria yang dipilih. Sebelum menentukan nilai keanggotaan, kriteria dibagi berdasarkan himpunan fuzzy linguistic yaitu kecil, sedang, tinggi yang terdapat dalam tabel 5 .

Tabel 5. Himpunan Fuzzy Linguistic

\begin{tabular}{|c|c|c|c|c|}
\hline No & Variabel & Kecil & Sedang & Tinggi \\
\hline 1 & $\begin{array}{l}\text { Harga } \\
\text { Kecil }\end{array}$ & 2000000 & - & 3500000 \\
\hline 2 & $\begin{array}{l}\text { Harga } \\
\text { Sedang }\end{array}$ & 3000000 & 4500000 & 6000000 \\
\hline 3 & $\begin{array}{l}\text { Harga } \\
\text { Tinggi }\end{array}$ & 5500000 & - & 8000000 \\
\hline 4 & $\begin{array}{l}\text { Kapasitas } \\
\text { Kecil }\end{array}$ & 4 & - & 6 \\
\hline 5 & $\begin{array}{l}\text { Kapasitas } \\
\text { Sedang }\end{array}$ & 5 & 7 & 9 \\
\hline 6 & $\begin{array}{l}\text { Kapasitas } \\
\text { Tinggi }\end{array}$ & 8 & - & 12 \\
\hline 7 & $\begin{array}{l}\text { Kecepatan } \\
\text { Kecil }\end{array}$ & 400 & - & 600 \\
\hline 8 & $\begin{array}{l}\text { Kecepatan } \\
\text { Sedang }\end{array}$ & 550 & 700 & 850 \\
\hline 9 & $\begin{array}{l}\text { Kecepatan } \\
\text { Tinggi }\end{array}$ & 800 & - & 1200 \\
\hline 10 & $\begin{array}{l}\text { Konsumsi } \\
\text { Kecil }\end{array}$ & 200 & - & 400 \\
\hline 11 & $\begin{array}{l}\text { Konsumsi } \\
\text { Sedang }\end{array}$ & 300 & 400 & 500 \\
\hline 12 & $\begin{array}{l}\text { Konsumsi } \\
\text { Tinggi }\end{array}$ & 450 & - & 600 \\
\hline 13 & $\begin{array}{l}\text { Berat } \\
\text { Kecil }\end{array}$ & 20 & - & 30 \\
\hline 14 & $\begin{array}{l}\text { Berat } \\
\text { Sedang }\end{array}$ & 25 & 35 & 50 \\
\hline 15 & $\begin{array}{l}\text { Berat } \\
\text { Tinggi }\end{array}$ & 45 & - & 60 \\
\hline 16 & $\begin{array}{l}\text { Panjang } \\
\text { Kecil }\end{array}$ & 50 & - & 65 \\
\hline 17 & $\begin{array}{l}\text { Panjang } \\
\text { Sedang }\end{array}$ & 60 & 65 & 75 \\
\hline 18 & $\begin{array}{l}\text { Panjang } \\
\text { Tinggi }\end{array}$ & 70 & - & 80 \\
\hline 19 & $\begin{array}{l}\text { Lebar } \\
\text { Kecil }\end{array}$ & 50 & - & 60 \\
\hline 20 & $\begin{array}{l}\text { Lebar } \\
\text { Sedang }\end{array}$ & 55 & 60 & 65 \\
\hline 21 & $\begin{array}{l}\text { Lebar } \\
\text { Tinggi }\end{array}$ & 60 & - & 70 \\
\hline 22 & $\begin{array}{l}\text { Tinggi } \\
\text { Kecil }\end{array}$ & 80 & - & 95 \\
\hline 23 & $\begin{array}{l}\text { TInggi } \\
\text { Sedang }\end{array}$ & 90 & 100 & 110 \\
\hline 24 & $\begin{array}{l}\text { Tinggi } \\
\text { Tinggi }\end{array}$ & 105 & - & 115 \\
\hline
\end{tabular}

Selanjutnya penentuan nilai keanggotaan pada masing-masing varibel yang sudah dikelompokkan. Apabila value kriteria mesin cuci termasuk ke dalam kriteria kecil dalam kelompok variabel fuzzy tahani, maka rumus yang digunakan sebagai berikut:

$$
\mu[x]=\left\{\begin{array}{cc}
0 ; & x \leq a \\
\frac{x-a}{b-a} ; & a \leq x \leq b \\
1 ; & x \geq b
\end{array}\right.
$$

Jika value kriteria mesin cuci termasuk ke dalam kriteria sedang, maka rumus yang digunakan adalah:

$$
\mu[x]=\left\{\begin{array}{cc}
0 ; & x \leq a \text { atau } x \geq c \\
\frac{x-a}{b-a} ; & a \leq x \leq b \\
\frac{c-x}{c-b} ; & b \leq x \leq c
\end{array}\right.
$$


Dan, jika value kriteria mesin cuci termasuk ke dalam kriteria tinggi, maka berikut rumus yang digunakan:

$$
\mu[x]=\left\{\begin{array}{cc}
\frac{b-x}{b-a} ; & a \leq x \leq b \\
0 ; & x \geq b
\end{array}\right.
$$

Dalam penelitian ini, penulis menggunakan tiga fungsi keanggotaan pada fuzzy yang dijadikan sebagai proses nilai input pada derajat keanggotaan nilai fuzzy yaitu representasi linier naik, representasi linier kurva segitiga dan representasi linier turun.

Diketahui seorang konsumen menginginkan mesin cuci dengan parameter harga kecil, kapasitas sedang dan kecepatan sedang. Berikut, perhitungan fuzzy tahani:

a. Menentukan Fungsi Keanggotaan

1) Harga Kecil

$$
\mu[x]=\left\{\begin{array}{cc}
0 ; & x \leq a \\
\frac{x-a}{b-a} ; & a \leq x \leq b \\
1 ; & x \geq b
\end{array}\right.
$$

$\mu[x]=\left\{\begin{array}{cc}0 ; & 2600000 \leq 2000000 \\ \frac{2600000-2000000}{3500000-2000000} ; & 2000000 \leq x \leq 3500000 \\ 1 ; & 2600000 \geq 3500000\end{array}\right.$

2) Kapasitas Sedang

$$
\begin{aligned}
& \mu[x]=\left\{\begin{array}{cc}
0 ; & x \leq \text { a atau } x \geq c \\
\frac{x-a}{b-a} ; & a \leq x \leq b \\
\frac{c-x}{c-b} ; & b \leq x \leq c
\end{array}\right. \\
& \mu[x]=\left\{\begin{array}{cc}
0 ; & 6 \leq 5 \text { atau } 6 \geq 9 \\
\frac{6-5}{7-5} ; & 5 \leq 6 \leq 7 \\
\frac{9-6}{9-7} ; & 7 \leq 6 \leq 9
\end{array}\right.
\end{aligned}
$$

3) Kecepatan Sedang

$$
\mu[x]=\left\{\begin{array}{lc}
0 ; & x \leq a \text { atau } x \geq c \\
\frac{x-a}{b-a} ; & a \leq x \leq b \\
\frac{c-x}{c-b} ; & b \leq x \leq c
\end{array}\right.
$$

$$
\mu[x]=\left\{\begin{array}{cc}
0 ; & 600 \leq 550 \text { atau } 600 \geq 850 \\
\frac{600-550}{700-550} ; & 550 \leq 600 \leq 700 \\
\frac{850-600}{850-700} ; & 700 \leq 600 \leq 850
\end{array}\right.
$$

\section{b. Fuzzyfikasi}

Berikut adalah hasil dari perhitungan fungsi keanggotaan dalam pemilihan mesin cuci:

1) Harga

Tabel 6. Hasil Perhitungan Kriteria Harga

\begin{tabular}{|l|l|l|l|l|}
\hline \multicolumn{5}{|c|}{ Nilai Keanggotaan Kriteria HARGA } \\
\hline Kriteria & Harga & Kecil & Sedang & Tinggi \\
\hline A1 & 2650000 & 0.567 & & \\
\hline A2 & 3000000 & 0.333 & & \\
\hline A3 & 3250000 & 0.167 & 0.167 & \\
\hline A4 & 3330000 & 0.113 & 0.22 & \\
\hline A5 & 5600000 & & 0.267 & 0.96 \\
\hline A6 & 6250000 & & & 0.7 \\
\hline A7 & 7000000 & & & 0.4 \\
\hline A8 & 7800000 & & & 0.08 \\
\hline A9 & 9000000 & & & 1 \\
\hline A10 & 10250000 & & & 1 \\
\hline
\end{tabular}

2) Kapasitas

Tabel 7. Hasil Perhitungan Kriteria Kapasitas

\begin{tabular}{|c|c|c|c|c|}
\hline \multicolumn{5}{|c|}{ Nilai Keanggotaan Kriteria KAPASITAS } \\
\hline Kriteria & Kapasitas & Kecil & Sedang & Tinggi \\
\hline A1 & 6 & & 0.5 & \\
\hline A2 & 6 & & 0.5 & \\
\hline A3 & 6 & & 0.5 & \\
\hline A4 & 7 & & 1 & \\
\hline A5 & 8 & & 0.5 & \\
\hline A6 & 10 & & & 0.5 \\
\hline A7 & 12 & & & 0 \\
\hline A8 & 10 & & & 0.5 \\
\hline A9 & 12 & & & 0 \\
\hline A10 & 13 & & & 1 \\
\hline
\end{tabular}

3) Kecepatan

Tabel 8. Hasil Perhitungan Kriteria Kecepatan

\begin{tabular}{|c|c|c|c|c|}
\hline \multicolumn{5}{|c|}{ Nilai Keanggotaan Kriteria KECEPATAN } \\
\hline Kriteria & Kecepatan & Kecil & Sedang & Tinggi \\
\hline A1 & 600 & & 0.333 & \\
\hline A2 & 700 & & 1 & \\
\hline A3 & 750 & & 0.667 & \\
\hline A4 & 800 & & 0.333 & \\
\hline A5 & 1000 & & & 0.5 \\
\hline A6 & 1100 & & & 0.75 \\
\hline A7 & 1200 & & & 1 \\
\hline A8 & 1250 & & & 1 \\
\hline A9 & 1400 & & & 1 \\
\hline A10 & 1200 & & & 1 \\
\hline \multicolumn{4}{|l}{} \\
\hline
\end{tabular}

\section{c. Fuzzyfikasi Query}

Pada tahap ini dilakukan penyeleksian proses fuzzyfikasi dengan ketentuan penggunaan operator sebagai kombinasi himpunan fuzzy. Berikut kententuan operator yang digunakan:

1) Variabel 1 beroperasi (OR) dengan variabel 2.

2) Variabel 2 beroperasi (AND) dengan variabel 3.

3) Variabel 3 beroperasi (OR) dengan variabel 4.

4) Variabel 4 beroperasi (AND) dengan variabel 5. 
5) Variabel 5 beroperasi (OR) dengan variabel 6.

6) Variabel 6 beroperasi (OR) dengan variabel 7.

7) Variabel 7 beroperasi (AND) dengan variabel 8.

Maka hasil yang didapat dari fuzzyfikasi quey adalah sebagai berikut:

Tabel 9. Hasil Urutan Fuzzy Tahani

\begin{tabular}{|c|c|c|c|c|c|c|c|c|c|c|}
\hline \multirow{2}{*}{$\begin{array}{l}\text { Krit } \\
\text { eria }\end{array}$} & \multicolumn{3}{|c|}{ Harga } & \multicolumn{3}{|c|}{ Kapasitas } & \multicolumn{3}{|c|}{ Kecepatan } & \multirow{2}{*}{$\begin{array}{l}\mathrm{Ha} \\
\text { sil }\end{array}$} \\
\hline & $\mathrm{K}$ & $\mathrm{S}$ & $T$ & $\mathrm{~K}$ & $S$ & $T$ & $\mathrm{~K}$ & $\mathrm{~S}$ & $T$ & \\
\hline $\mathrm{A} 1$ & $\begin{array}{l}0.56 \\
67\end{array}$ & 0 & 0 & 0 & $\begin{array}{l}0 . \\
5\end{array}$ & 0 & 0 & $\begin{array}{l}0.33 \\
33 \\
\end{array}$ & 0 & 0.3 \\
\hline A2 & $\begin{array}{l}0.33 \\
33\end{array}$ & 0 & 0 & 0 & 1 & 0 & 0 & 1 & 0 & 1 \\
\hline $\mathrm{A} 3$ & $\begin{array}{l}0.16 \\
67 \\
\end{array}$ & $\begin{array}{l}0.16 \\
67 \\
\end{array}$ & 0 & 0 & $\begin{array}{l}0 . \\
5\end{array}$ & 0 & 0 & $\begin{array}{l}0.66 \\
67\end{array}$ & 0 & 0.5 \\
\hline A4 & 0.22 & 0.22 & 0 & 0 & 0 & $\begin{array}{l}0 . \\
5\end{array}$ & 0 & $\begin{array}{l}0.33 \\
33\end{array}$ & 0 & $\begin{array}{l}0.2 \\
2\end{array}$ \\
\hline A5 & 0 & $\begin{array}{l}0.26 \\
67 \\
\end{array}$ & $\begin{array}{l}0 . \\
04 \\
\end{array}$ & 0 & $\begin{array}{l}0 . \\
5 \\
\end{array}$ & 0 & 0 & 0 & $\begin{array}{l}0 . \\
5 \\
\end{array}$ & 0 \\
\hline A6 & 0 & 0 & $\begin{array}{l}0 . \\
3 \\
\end{array}$ & 0 & 0 & $\begin{array}{l}0 . \\
5\end{array}$ & 0 & 0 & $\begin{array}{l}0 . \\
75 \\
\end{array}$ & 0 \\
\hline A7 & 0 & 0 & $\begin{array}{l}0 . \\
6\end{array}$ & 0 & 0 & 1 & 0 & 0 & 1 & 0 \\
\hline A8 & 0 & 0 & $\begin{array}{l}0 . \\
92\end{array}$ & 0 & 0 & $\begin{array}{l}0 . \\
5\end{array}$ & 0 & 0 & 1 & 0 \\
\hline A9 & 0 & 0 & 1 & 0 & 0 & 1 & 0 & 0 & 1 & 0 \\
\hline $\mathrm{A} 10$ & 0 & 0 & 1 & 0 & 0 & 1 & 0 & 0 & 1 & 0 \\
\hline
\end{tabular}

\subsection{Perhitungan Promethee}

Diketahui urutan dan bobot kriteria mesin cuci rumah tangga yang telah dihitung menggunakan metode SMART. Berikut hasil urutan dan bobot kriteria mesin cuci rumah tangga yang terdapat pada tabel 10.

Tabel 10. Urutan dan Bobot Kriteria Mesin Cuci Rumah Tangga

\begin{tabular}{|l|c|c|}
\hline \multicolumn{1}{|c|}{ Kriteria } & Rangking & Persentase \\
\hline Merk & 1 & $45.7 \%$ \\
\hline Sumber Air & 5 & $4.0 \%$ \\
\hline Garansi & 2 & $25.7 \%$ \\
\hline Jumlah Keluarga & 3 & $15.7 \%$ \\
\hline Kondisi Kesibukan & 4 & $9.0 \%$ \\
\hline
\end{tabular}

Berikut langkah-langkah perhitungan promethee:

a. Menghitung Prosentase

Tabel 11. Prosentase

\begin{tabular}{|c|c|c|c|c|c|c|}
\hline Kriteria & A1 & A2 & A3 & A4 & $\begin{array}{l}\text { Tipe } \\
\text { Preferens } \\
\text { i }\end{array}$ & $\begin{array}{l}\text { Paramete } \\
\mathrm{r}\end{array}$ \\
\hline Merk & $\begin{array}{l}1.3 \\
7\end{array}$ & $\begin{array}{l}1.3 \\
7\end{array}$ & $\begin{array}{l}1.3 \\
7\end{array}$ & 1.37 & 2 & $q=2$ \\
\hline Air & $\begin{array}{l}0.1 \\
2\end{array}$ & $\begin{array}{l}0.1 \\
2\end{array}$ & $\begin{array}{l}0.0 \\
4\end{array}$ & 0.04 & 2 & $q=2$ \\
\hline Garansi & $\begin{array}{l}0.2 \\
6\end{array}$ & $\begin{array}{l}0.7 \\
7\end{array}$ & $\begin{array}{l}0.7 \\
7\end{array}$ & 0.77 & 3 & $p=2$ \\
\hline Keluarga & $\begin{array}{l}0.4 \\
7\end{array}$ & $\begin{array}{l}0.4 \\
7\end{array}$ & $\begin{array}{l}0.4 \\
7\end{array}$ & $\begin{array}{l}0.31 \\
4\end{array}$ & 3 & $p=2$ \\
\hline $\begin{array}{l}\text { Kesibuka } \\
\text { n }\end{array}$ & $\begin{array}{l}0.2 \\
7\end{array}$ & $\begin{array}{l}0.2 \\
7\end{array}$ & $\begin{array}{l}0.0 \\
9\end{array}$ & 0.09 & 2 & $q=2$ \\
\hline
\end{tabular}

b. Menentukan tipe preferensi untuk kriteria Merk, Air dan Kesibukan.

1) Jika tipe preferensi bernilai 2, rumus yg digunakan adalah Quansi:

a) $\mathrm{H}(\mathrm{d})=0$, jika $(\mathrm{d}>=-\mathrm{q})$ dan $(\mathrm{d}$ $<=\mathrm{q})$

b) $\mathrm{H}(\mathrm{d})=1$, jika $(\mathrm{d}<-\mathrm{q})$ atau $(\mathrm{d}>$ q)

Tabel 12. Tipe Preferensi Merk

\begin{tabular}{|l|r|r|r|r|}
\hline $\begin{array}{l}\text { Kriteria: } \\
\text { Merk }\end{array}$ & A1 & A2 & A3 & A4 \\
\hline A1 & & 0 & 0 & 0 \\
\hline A2 & 0 & & 0 & 0 \\
\hline A3 & 0 & 0 & & 0 \\
\hline A4 & 0 & 0 & 0 & \\
\hline
\end{tabular}

Tabel 13. Tipe Preferensi Air

\begin{tabular}{|l|r|r|r|r|}
\hline $\begin{array}{l}\text { Kriteria: } \\
\text { Air }\end{array}$ & \multicolumn{1}{|c|}{ A1 } & \multicolumn{1}{|c|}{ A2 } & A3 & \multicolumn{1}{|c|}{ A4 } \\
\hline A1 & & 0 & 0.08 & 0.08 \\
\hline A2 & 0 & & 0.08 & 0.08 \\
\hline A3 & -0.08 & -0.08 & & 0 \\
\hline A4 & -0.08 & -0.08 & 0 & \\
\hline
\end{tabular}

Tabel 14. Tipe Preferensi Kesibukan

\begin{tabular}{|l|r|r|r|r|}
\hline $\begin{array}{l}\text { Kriteria: } \\
\text { Kesibukan }\end{array}$ & \multicolumn{1}{|c|}{ A1 } & A2 & A3 & \multicolumn{1}{c|}{ A4 } \\
\hline A1 & & 0 & 0.18 & 0.18 \\
\hline A2 & 0 & & 0.18 & 0.18 \\
\hline A3 & -0.18 & -0.18 & & 0 \\
\hline A4 & -0.18 & -0.18 & 0 & \\
\hline
\end{tabular}

2) Jika tipe preferensi bernilai 3, rumus yg digunakan adalah Linier:

a) $H(d)=(d / p)$, jika $(d>=-p)$ dan $(d<=p)$

b) $H(d)=1$, jika $(d<-p)$ atau $(d>$ p)

Tabel 16. Tipe Preferensi Garansi

\begin{tabular}{|l|l|l|l|l|}
\hline $\begin{array}{l}\text { Kriteria } \\
\text { Garansi }\end{array}$ & A1 & A2 & A3 & A4 \\
\hline A1 & & -0.1713 & -0.1713 & -0.1713 \\
\hline A2 & 0.1713 & & 0 & 0 \\
\hline A3 & 0.1713 & 0 & & 0 \\
\hline A4 & 0.1713 & 0 & 0 & \\
\hline
\end{tabular}

Tabel 16. Tipe Preferensi Keluarga

\begin{tabular}{|l|l|l|l|l|}
\hline $\begin{array}{l}\text { Kriteria } \\
\text { Keluarga }\end{array}$ & A1 & A2a & A3 & A4 \\
\hline A1 & & 0 & 0 & 0.0523 \\
\hline A2 & 0 & & 0 & 0.0523 \\
\hline A3 & 0 & 0 & & 0.0523 \\
\hline A4 & -0.0523 & -0.0523 & -0.0523 & \\
\hline
\end{tabular}

c. Menentukan Indeks Preferensi

Perhitungan indeks preferensi menggunakan rumus sebagai berikut:

$$
V=\frac{1}{v} x(v 1+v 2+v 3+v 5)
$$




\begin{tabular}{|l|l|l|l|l|}
\hline \multicolumn{5}{|c|}{ Tabel 17. Indeks Preferensi } \\
\hline Kriteria & A1 & A2 & A3 & A4 \\
\hline A1 & & - & 0.17733 & 0.0282 \\
& & 0.0343 & & \\
\hline A2 & 0.034267 & & 0.052 & 0.06247 \\
\hline A3 & -0.017 & -0.052 & & 0.01047 \\
\hline A4 & -0.028 & - & -0.0105 & \\
\hline
\end{tabular}

d. Menghitung Leaving Flow

Perhitungan leaving flow menggunakan rumus seperti berikut:

$$
\varnothing+(a)=\left[\frac{1}{n-1}\right] \sum_{x \in A} \varphi(x, a)
$$

Tabel 18. Leaving Flow

\begin{tabular}{|l|l|l|l|l|l|}
\hline Kriteria & \multicolumn{1}{|c|}{ A1 } & \multicolumn{1}{|c|}{ A2 } & \multicolumn{1}{|c|}{ A3 } & A4 & $\begin{array}{c}\text { Leaving } \\
\text { Flow }\end{array}$ \\
\hline A1 & & -0.03426 & 0.01773 & 0.0282 & $\mathbf{0 . 0 0 3 8 8}$ \\
\hline A2 & 0.03427 & & 0.052 & 0.0625 & $\mathbf{0 . 0 4 9 5 7}$ \\
\hline A3 & -0.0177 & -0.052 & & 0.0105 & $\mathbf{- 0 . 0 1 9 8}$ \\
\hline A4 & -0.0282 & -0.0625 & -0.0105 & & $\mathbf{- 0 . 0 3 3 7}$ \\
\hline
\end{tabular}

e. Menghitung Entering Flow

Perhitungan entering flow

menggunakan rumus seperti berikut:

$$
\varnothing-(a)=\left[\frac{1}{n-1}\right] \sum_{x \in A} \varphi(x, a)
$$

Tabel 19. Entering Flow

\begin{tabular}{|c|c|c|c|c|}
\hline Kriteria & $\mathrm{A} 1$ & $\mathrm{~A} 2$ & $\mathrm{~A} 3$ & $\mathrm{~A} 4$ \\
\hline $\mathrm{A} 1$ & & -0.03427 & 0.01773 & 0.0282 \\
\hline $\mathrm{A} 2$ & 0.03427 & & 0.052 & 0.06247 \\
\hline $\mathrm{A} 3$ & -0.01773 & -0.052 & & 0.01047 \\
\hline $\mathrm{A} 4$ & -0.0282 & -0.06247 & -0.01047 & \\
\hline $\begin{array}{l}\text { Entering } \\
\text { Flow }\end{array}$ & $\mathbf{- 0 . 0 0 3 8 9}$ & $\mathbf{- 0 . 0 4 9 5 8}$ & $\mathbf{0 . 0 1 9 7 6}$ & $\mathbf{0 . 0 3 3 7 1}$ \\
\hline
\end{tabular}

f. Menghitung Net Flow

Hasil akhir dari perhitungan promethee yaitu leaving flow - entering flow. Berikut rumus yang digunakan:

$$
\varnothing(a)=\varnothing+(a)-\emptyset-(a)
$$

Tabel 20. Net Flow

\begin{tabular}{|l|c|c|c|c|}
\hline Kriteria & $\begin{array}{c}\text { Leaving } \\
\text { Flow }\end{array}$ & $\begin{array}{c}\text { Entering } \\
\text { Flow }\end{array}$ & $\begin{array}{c}\text { Net } \\
\text { Flow }\end{array}$ & Urut \\
\hline A1 & 0.00389 & -0.0038 & 0.00778 & 2 \\
\hline A2 & 0.04958 & -0.0495 & 0.09915 & 1 \\
\hline A3 & -0.0197 & 0.0197 & -0.0395 & 3 \\
\hline A4 & -0.0337 & 0.0337 & -0.0674 & 4 \\
\hline
\end{tabular}

Dari tabel 20 dapat dilihat bahwa hasil dari pemilihan mesin cuci menggunakan fuzzy tahani dan promethee adalah mesin cuci A2. Dapat dilihat dari hasil net flow yang mendekati 1.

\section{Kesimpulan}

Berdasarkan hasil dan pembahasan yang telah dilakukan, dapat disimpulkan bawah proses pemilihan mesin cuci menggunakan metode fuzzy tahani menghasilkan urutan rekomendasi mesin cuci yang masing-masing hasil bernilai dari 0 sampai 1 , dengan beberapa tahapan seperti menentukan kriteria, menggambarkan fungsi keanggotaan dan operasi dasar zadeh untuk operasi himpunan fuzzy.

Metode promethee, digunakan untuk mendapatkan bobot mesin cuci berupa netflow dan sebagai hasil akhir dalam pengurutan mesin cuci berdasarkan netflow secara ascending yang nantinya menjadi rekomendasi bagi para konsumen.

Proses pemilihan mesin cuci menggunakan metode fuzzy tahani dan promehtee menghasilkan kebutuhan mesin cuci untuk konsumen yang memiliki sedikit waktu luang dapat memilih mesin cuci dengan satu tabung, apabila konsumen memiliki banyak waktu luang dapat memilih mesin cuci dengan dua tabung dan untuk konsumen yang akan membuka usaha bisnis (laundry) dapat memilih mesin cuci dengan front load atau tabung depan. Sedangkan, untuk akurasi sistem yang dihasilkan sebesar $90 \%$ dari data yang diuji.

\section{Referensi}

Arisandi, Satria, M. I., \& S. Sagala, L. H. (2016). Sistem Penunjang Keputusan Pemilihan Hotel di Kota Kendari Menggunakan Metode Fuzzy Tahani Berbasis Web. Sistem Pendukung Keputusan.

Astria, R. (2013, April 21). PENJUALAN ELEKTONIKA: Mesin Cuci Penopang Terbesar Pada Kuartal I. Diambil kembali dari Industri Bisnis: http://industri.bisnis.com/read/2013 0421/257/9930/penjualanelektonika-mesin-cuci-penopangterbesar-pada-kuartal-i

Julianto, L., Setiawan, N. A., \& Aji, M. N. (2013, February). Rancang Bangun Sistem Pendukung Keputusan Pemilihan Mahasiswa Berprestasi Menggunakan Metode AHP dan Promethee. Jurnal Sistem Pendukung Keputusan, II(4), 9.

Kahar, N. (2013). Sistem Pendukung Keputusan Penerima Jamkesda Di Kota Jambi (Vol. I). Jambi: Konferensi Nasional Informatika.

Kazan, H., Ozcelik, S., \& Hobikoglu, E. H. (2015). Pemilihan Kandidat Deputi untuk Nominasi Partai Politik 
dengan Metode AHP dan Promethee. Sistem Pendukung Keputusan.

Kuncahyo, B. Ginardi, R. \& Arieshanti, I. (2012). Penerapan Metode Adaptive Neuro-Fuzzy Inference System untuk Meprediksi Nilai Post Test Mahasiswa. Surabaya: Jurusan Teknik Informatika FTIF ITS. Fakultas Teknologi Informasi,.

Kusumadewi, Sri., \& Hartati. (2006). Fuzzy Neuro-Fuzzy (Integrasi sistem Fuzzy dan jaringan syarat). Yogyakarta: Graha IImu.

Lemantara, J., Setiawan, N. A., \& Aji, M. N. (2014, Maret). Rancang Bangun Sistem Pendukung Keputusan Pemilihan Mahasiswa Berprestasi Menggunakan Metode AHP dan Promethee. JNTETI, 5(1), 25-34.

Murat, S., Kazan, H., \& Coskun, S. (2015). Aplikasi untuk Mengukur Kualitas Performa pada Sekolah Menggunakan Promethee Metode Pengambil Keputusan Multi Kriteria. Sistem Pendukung Keputusan.

Rahmatullah, D. A., Prassetiyo, H., \& Imran, A. (2013). Usulan Prioritas Peringkat dalam Pemilihan Supplier Produk Yamato dengan Metode Promethee. Sistem Pendukung Keputusan.

Rusman, A. (2016). Logika Fuzzy Tahani Sistem Penunjang Keputusan Penentuan Lulusan Terbaik. Sistem Pendukung Keputusan.

Suryadi \& Ramdhani. (2002). Sistem Pendukung Keputusan Suatu Wacana Struktural Idealisasi dan Implementasi Konsep Pengambilan Keputusan. Bandung: PT. Remaja Rosdakarya.

Taufiq, G. (2016, March 1). Implementasi Logika Fuzzy Tahani untuk Model Sistem Pendukung Kepurtusan Evaluasi Kinerja Karyawan. Jurnal Sistem Pendukung Keputusan, XII, 9. Dipetik May 24, 2017
Trinorosimo. P., \& Sumiati. (2014). Penerapan Metode Fuzzy Tahani Dalam Pemilihan Konsultasi Manajemen Konstruksi.

Tyas. (2013, February). Jenis-jenis Fungsi Keanggotaan. Dipetik May 23, 2017, dari Informatika: http://informatika.web.id/jenis-jenisfungsi-keanggotaan.htm

Widodo, S., \& Utomo, V. G. (2014, March 1). Rancang Bangun Aplikasi Travel Recommender Berbasis WAP Menggunakan Metode Fuzzy Model Tahani (Studi Kota Semarang). Jurnal Teknologi Informasi dan Komunikasi, 5, 2.

Yunus, M., Dahlan, H. S., \& Santoso, P. B. (2014, June 1). SPK Pemilihan Calon Pendonor Darah Potensial dengan Algoritma C4.5 dan Fuzzy tahani. Jurnal Sistem Pendukung Keputusan, 8, 8. 